Article

\title{
Quantifying Impacts of Forest Recovery on Water Yield in Two Large Watersheds in the Cold Region of Northeast China
}

\author{
Liangliang Duan (1) and Tijiu Cai * \\ Department of Forestry, School of Forestry, Northeast Forestry University, Harbin 150040, China; \\ liangliang.duan@nefu.edu.cn \\ * Correspondence: caitijiu1963@163.com; Tel.: +86-04-1882191821
}

Received: 12 June 2018; Accepted: 29 June 2018; Published: 3 July 2018

check for updates

\begin{abstract}
In northern China, large-scale reforestations were implemented to restore the ecosystem functions (e.g., hydrology function). However, few studies have been conducted to quantify the relative contributions of forest recovery to water yield in boreal forest region across the globe. In this study, the impacts of forest recovery on the changes in mean annual water yield were assessed in two large forested watersheds in the boreal forest region of northeast China using three different approaches. As commonly considered, the results confirmed that forest recovery was the dominant driver of the reductions in annual water yield in the two watersheds in the past three decades (1987-2016), explaining 64.3\% (15.4 $\mathrm{mm})$ and $87.4 \%(40.7 \mathrm{~mm})$ of variations in annual water yield for Upper Tahe watershed (UTH) and Xinancha watershed (XNC), respectively. By contrast, climate variability played minor role in annual water yield variation, explaining only $35.7 \%(8.5 \mathrm{~mm})$ and $12.6 \%$ (7.2 mm) for UTH and XNC, respectively. The response differences between the two watersheds may mainly be attributed to differences in forest type, topography and climate regimes. This study provided important insight into sustainable forest and water resources management in the region.
\end{abstract}

Keywords: reforestation; annual water yield; forest hydrology; boreal forest; relative contribution

\section{Introduction}

The large-scale reforestation programs have greatly increased forest coverage in China since the 1980s, restoring ecosystem services and benefits of the communities [1]. Despite the positive effects of reforestation in ecosystems restoration, the massive afforestation was also considered a threat to the water resources or supply in some regions [2]. For example, Qiu [3] reported that reforestation may potentially contribute to the droughts in Southwest China. Although numerous existing studies were dedicated to assessing the impacts of reforestation on water yield globally with varying numbers of watersheds and watershed sizes, as reviewed by Zhang et al. [4] and Li et al. [5], there exists limited studies [6,7] examining the effects of afforestation and reforestation on water yield in boreal regions, and, particularly, a lack of studies in the boreal forest region in China [8]. This raises a critical need to study such effects in the boreal regions to enrich our knowledge of the relationship between forest recovery and water resources.

In addition to forest recovery, climate change is also a critical driver to the hydrology in large forested watersheds [9-11]. For instance, Li et al. [5] reported that forest and climate played a co-equal role in hydrological variations. Wei et al. [11] found that forest change can only explain $30 \%$ of hydrological variations in the global forested regions in the period of 2000-2011. This further highlighted the importance of considering both forest and climate change in watershed assessment.

To quantify the relative contribution of forest cover change to the changes in water yield, the effects of climate variability have to be removed or quantified firstly. Several recent studies have 
successfully separated the relative impacts of forest cover change and climate variability on water yield in large watersheds using different methods. For instance, Wei and Zhang [9] and Zhang and Wei [12] applied Modified Double-Mass Curve (MDMC) to quantify the relative contributions of the changes in forest cover to water yield in large forested watersheds in Canada and China, respectively. Zhao et al. [13] used Time Trend Analysis (TRA) and Sensitivity-Based Methods (SBM) to separate the effects of vegetation change and the effects of climate variability on streamflow in different catchments in New Zealand, South Africa and Australia, respectively. The Budyko Framework (BF) is also widely used to quantify the impacts of vegetation changes on streamflow [14-16]. Wei et al. [17] compared pros and cons of eight methods for quantifying the relative contribution of forest or land cover change and climatic variability to hydrology in large watersheds and concluded that each method must be supplemented by other methods to achieve a robust conclusion. In this study, we applied three methods including MDMC, TRA and SBM to get the reliable results.

The cold region of Northeast China can be typically represented by the boreal coniferous forest in the Da Hinggan Mountains [18] and the boreal/temperate transition mixed coniferous and broadleaved forest in the Xiao Hinggan Mountains [19], respectively. These forests experienced long-term timber harvesting from the 1960s to 1990s and a forest recovery period through natural forest protection projects in the late 1990s [20]. As a result, the forest coverage has greatly increased in the past three decades, which provides a suitable base for investigating the interactions between forest recovery and water yield in this region.

Two large forested watersheds including Upper Tahe (UTH) watershed and Xinancha (XNC) watershed in the cold region of Northeast China were selected for this study. Long-term (1987-2016) forest cover and hydrometeorological data were used: (1) to quantify the relative contributions of forest recovery to the long-term water yield; (2) to examine the sensitivity of annual water yield to forest recovery; and (3) to explore the implications of our research findings for watershed management in the cold region.

\section{Materials and Methods}

\subsection{Study Watersheds}

The UTH watershed and XNC watershed have drainage areas of 2359 and $2582 \mathrm{~km}^{2}$, respectively, and are located in Heilongjiang Province in the high latitude cold region of Northeast China (Figure 1a). According to Chinese vegetation database administrated by Data Center for Resources and Environmental Sciences, Chinese Academy of Sciences (RESDC), the UTH watershed is zoned in boreal coniferous forests, while XNC watershed is zoned in the boreal/temperate transition mixed coniferous and broadleaved forest (Figure 1b). The two watersheds are both dominated by gentle hills with the average slope of $12.5^{\circ}$ and $13.4^{\circ}$, respectively, and the elevations range from 96 to $1276 \mathrm{~m}$ above sea level (Figure 1c,d). Both watersheds are dominated by dark brown earths and brown coniferous forest soils. The main characteristics of two watersheds are summarized in Table 1. According to the Circum-Arctic Map of Permafrost and Ground Ice Conditions, Version 2 (http:/ / nsidc.org/data/ggd318\#) [21], the UTH watershed spans discontinuous and sporadic permafrost zones, while the XNC watershed spans seasonal frozen ground without permafrost. It should be noted that warming climate might further enhance permafrost thaw particularly in boreal regions [22,23]. The permafrost thaw can alter the regional hydrological processes $[24,25]$. Therefore, to minimize the effects of permafrost thawing on streamflow, the period from 1987 to 2016 with a relative stable mean annual air temperature, as found by Duan et al. [8] and Duan et al. [26], was selected to quantify the relative contribution of forest recovery on water yield in this study. 


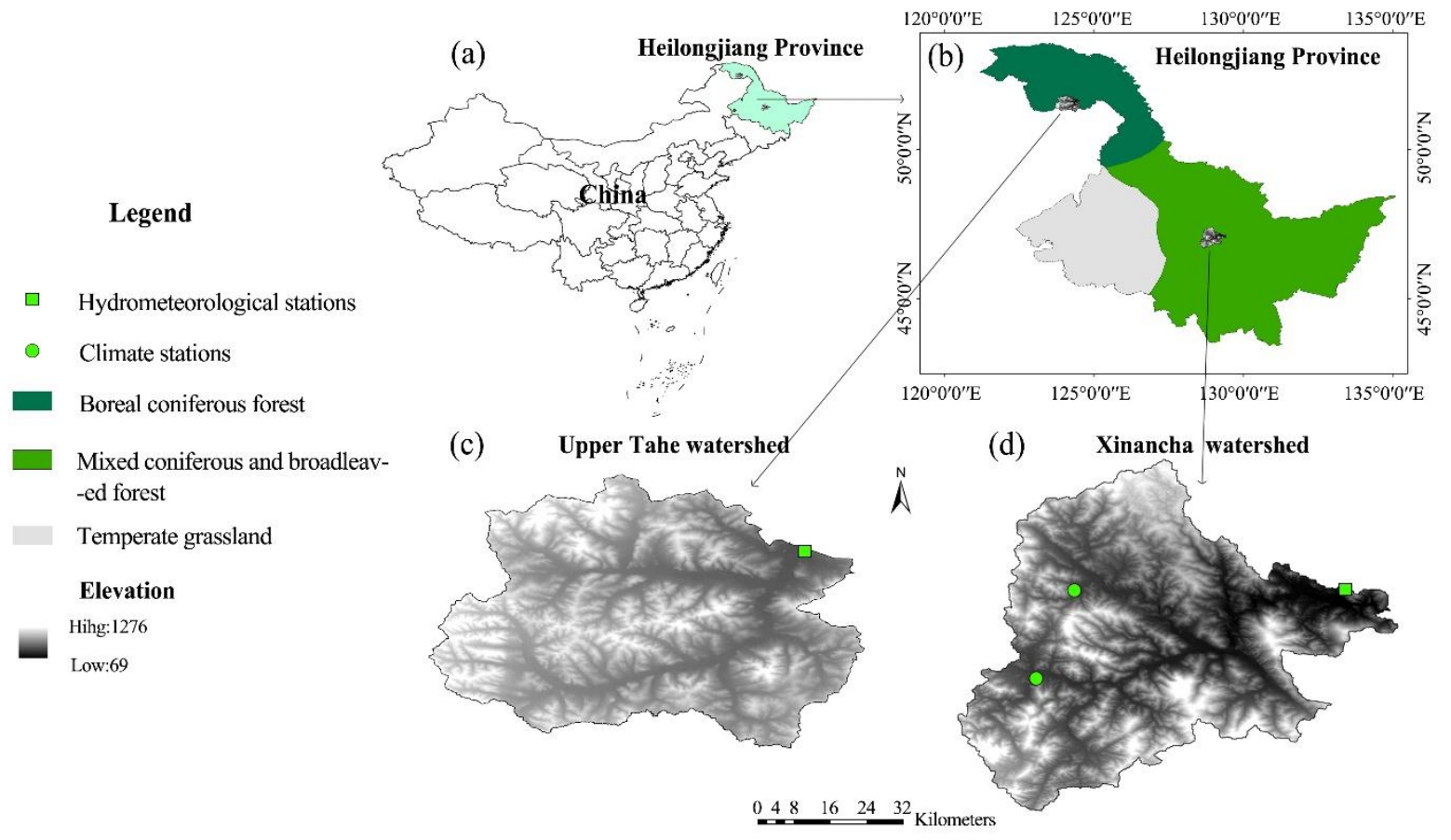

Figure 1. Locations (a); forest types (b); topography of the UTH watershed (c); and topography of the XNC watershed $(\mathbf{d})$.

Table 1. Watershed characteristics for the UTH watershed and XNC watershed.

\begin{tabular}{lll}
\hline Metrics & UTH Watershed & XNC Watershed \\
\hline Drainage area $\left(\mathrm{km}^{2}\right)$ & 2359 & 2582 \\
Mainstream length $(\mathrm{km})$ & 83 & 82 \\
Average elevation $(\mathrm{m})$ & 783 & 501 \\
Elevation range $(\mathrm{m})$ & $432-1276$ & $69-1226$ \\
Average slope $\left({ }^{\circ}\right)$ & 12.5 & 13.4 \\
Soil type & Dark brown earths and brown & Dark brown earths and brown \\
Annual mean precipitation $(\mathrm{mm})$ & coniferous forest soil & coniferous forest soil \\
Annual mean PET $(\mathrm{mm})$ & 520.5 & 706.0 \\
Annual mean air temperature $\left({ }^{\circ} \mathrm{C}\right)$ & -2.1 & 711.8 \\
Annual mean flow $(\mathrm{mm})$ & 297.3 & 2.4 \\
Average forest cover $(\%)$ & 75.6 & 298.7 \\
Forest type & Boreal coniferous forest & 87.7 \\
Hydrometric station & Xinlin & Mixed coniferous and broadleaved \\
Climate stations & Xinlin & forest \\
\hline
\end{tabular}

The two study watersheds are characterized by a typical continental monsoon climate. Based on the climate data from 1987 to 2016, the average annual precipitation of two watersheds are 534.8 and $706.0 \mathrm{~mm}$ for the UTH and XNC, respectively, of which approximately $85 \%$ occurs as rain from May to September (the wet season) (Figure 2). The average annual air temperature for the UTH and XNC watersheds is -2.1 and $2.4^{\circ} \mathrm{C}$, respectively, with the average highest and lowest occurring in July and January, respectively (Figure 2). The UTH watershed is located in the boreal coniferous forest zone, where the native vegetation consists of forest communities dominated by larch (Larix gmelinii), along with broadleaf species, such as birch (Betula platyphylla). The XNC watershed is in the boreal/temperate transition mixed coniferous and broadleaved forest zone, where the flora is more diverse [18]. In this region, the coniferous forest is dominated by Korean pine (Pinus koraiensis), and the broadleaved 
species mainly include Tilia amurensis, Fraxinus mandschurica, and Mongolian oak (Quercus mongolica). The forests were mainly regenerated from the natural forest succession with the major secondary forests of birch in UTH watershed and Mongolian oak forest in XNC watershed.
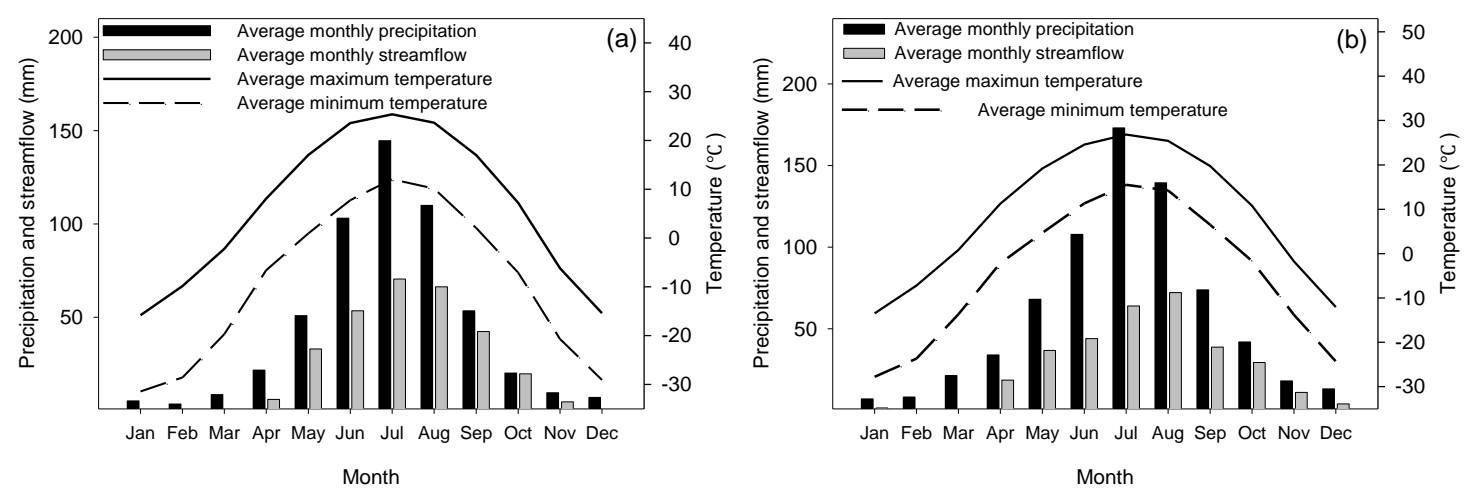

Figure 2. Average monthly streamflow, precipitation, and air temperature in the UTH (a) and XNC (b) watersheds from 1987 to 2016.

\subsection{Data}

\subsubsection{Forest Cover Data}

Annual forest cover data from 1987 to 2016 were obtained from the forest resource inventory database administrated by the Xinlin Forestry and Yichun Forestry Bureaus [8,27], respectively. Following the protocol of "Observation Methodology for Long-term Forest Ecosystem Research" of the National Standards of the People's Republic of China (GB/T 33027-2016), the forest coverage was calculated as percent ratio of all forest area with canopy coverage greater than $30 \%$ over the total area of the study watershed. As shown in Figure 3, the forest cover of two study watersheds showed a significantly positive trend ( $p<0.001$, Mann-Kendall test) during the entire study period. The Pettitt's Tests [28] indicated that the forest coverage of UTH and XNC watersheds had the statistically significant change points in 2002 and $2000(p<0.05)$, respectively. The forest coverage of UTH watershed did not show very much change from 1987 to 2002 with the average of $70.2 \%$, but increased from $72.2 \%$ to $87.5 \%$ from 2003 to 2016 (Figure 3). The forest coverage of XNC watershed increased from $75.8 \%$ to $86.6 \%$ from 1987 to 2000 , and showed a slightly increasing trend from 2001 to 2016 with the average of $88.4 \%$.

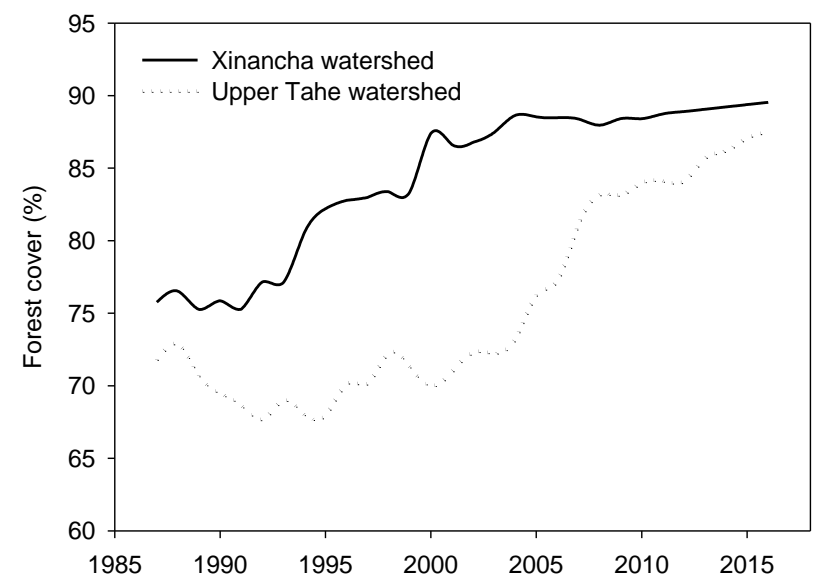

Figure 3. Forest cover (\%) from 1987 to 2016 in UTH watershed and XNC watershed. 


\subsubsection{Hydrometeorological Data}

The annual and seasonal streamflow data from 1987 to 2016 were both produced by the aggregation of daily streamflow data, which were calculated based on the relationship between streamflow and discharge stage height collected at the Xinlin and Nancha hydrometric stations (Figure 1), respectively. The details on annual streamflow, Annual peak flows, the monthly precipitation, monthly mean, maximum and minimum air temperatures, and monthly sunshine hours from 1987 to 2016 are shown in Table 1. The averaged watershed-based precipitation estimates were derived by the Thiessen polygon method for XNC watershed. To understand the relative contribution of seasonal streamflow variations to annual streamflow changes, streamflow data from the entire year was summarized into four seasons: spring (April to May), summer (June to August), autumn (September to October), and winter (November to March).

\subsection{Data Analysis Methods}

\subsubsection{Trend Analysis on Hydrological and Climatic Series}

Trend analysis is useful for understanding dynamics of hydrological and climatic variables over a long-term period [29,30]. A nonparametric trend test, namely the Mann-Kendall test [31,32], was adopted to detect whether significant trends exist in the long-term hydrological and climatic data [29]. The magnitude of the trend, $\beta$, or the slope (change per unit time) was used to describe the change rate of long-term hydrological and climatic variables, which was estimated using the Sen's slope method $[33,34]$ as follows:

$$
\beta=\operatorname{Median}\left[\frac{X_{j}-X_{i}}{j-i}\right] \text { for all } i<j
$$

where $1<i<j<n$ and is the median of all possible combinations of pairs for the entire data set.

\subsubsection{Time Series Correlation Analysis}

Annual time series of hydrological and forest cover data were used to conduct cross-correlation analyses for the entire study period and detect statistical relationships between these data sets. To eliminate the autocorrelations in the data series, all data series were pre-whitened using the best fitting autoregressive integrated moving average models (ARIMA) [35,36]. Then, residual series were used in the cross-correlation analysis. These analyses were conducted using the software STATISTICA 7 (StatSoft ${ }^{\circledR}$, Palo Alto, CA, United States).

\subsubsection{Separation of the Impacts of Climatic Variability and Forest Recovery on Annual Streamflow}

\section{Modified Double Mass Curve Method}

Modified Double Mass Curve (MDMC) developed by Wei and Zhang [9] was firstly used to separate the relative contributions of climate variability and forest recovery on annual streamflow and detect the break point in annual streamflow caused by forest recovery. The modified double mass curve assumes that there is a linear relation between streamflow and effective precipitation, and plots accumulated annual streamflow versus accumulated annual effective precipitation. The annual effective precipitation refers to the difference between annual precipitation and annual evapotranspiration [9]. In the period when there are no significant impacts of forest cover change on annual streamflow, a straight line should be expected to describe the relation between annual streamflow and annual effective precipitation. However, with a management or other disturbances in the forest, a curve line with a turning point would be expected. The statistical significance of the break points was confirmed by the interrupted ARIMA model.

Once the statistical significance of the break point was confirmed, the whole study period was subsequently divided into reference (before the break point) and forest recovery (after the break point) periods. The difference between the average observed annual streamflow $\left(Q_{2}\right)$ and the average annual 
streamflow predicted by the baseline in the forest recovery period can be attributed to the effects of forest recovery on annual streamflow $\left(\Delta Q_{F}\right)$. The variation of annual streamflow caused by climate change $\left(\Delta Q_{C}\right)$ can be determined as:

$$
\Delta Q_{C}=\Delta Q-\Delta Q_{F}
$$

where $\Delta Q$ is the deviation of average annual streamflow between forest recovery period and reference period:

$$
\Delta Q=Q_{2}-Q_{1}
$$

where $Q_{1}$ and $Q_{2}$ are the average annual streamflow in the reference and forest recovery periods, respectively.

The relative contributions of forest recovery and climate variability to the changes in mean annual streamflow can be estimated as:

$$
\begin{aligned}
& R_{F}=\frac{\left|\Delta Q_{F}\right|}{\left|\Delta Q_{F}\right|+\left|\Delta Q_{C}\right|} \times 100 \% \\
& R_{C}=\frac{\left|\Delta Q_{C}\right|}{\left|\Delta Q_{F}\right|+\left|\Delta Q_{C}\right|} \times 100 \%
\end{aligned}
$$

In this study, potential evapotranspiration is estimated using the temperature-based Hamon method [37], which has been shown to provide reasonable potential evapotranspiration for forested regions $[8,38,39]$ :

$$
P E T=0.1651 \times D \times V_{d} \times K \times N
$$

where $D$ is the monthly average time from sunrise to sunset (from the climate station) in multiples of $12 \mathrm{~h}, V_{d}$ is the saturated vapor density $\left(\mathrm{g} \mathrm{m}^{-3}\right)$ at the monthly mean air temperature $\left(\mathrm{T},{ }^{\circ} \mathrm{C}\right)$ as shown in Equation (7), and $N$ is the number of days in each month.

$$
V_{d}=216.7 \times \frac{V_{s}}{T+273.3}
$$

$V_{S}$ is the saturated vapor pressure (millibars), expressed as:

$$
V_{S}=6.108 \times \exp \left[17.26939 \times \frac{T}{T+273.3}\right]
$$

where $\mathrm{K}$ is a correction coefficient to adjust PET from the Hamon's method to reflect realistic values for PET. The reported K values range from 1.0 to 1.4 [37,39]. Due to the expected low potential evapotranspiration in the cold study watersheds, the $\mathrm{K}$ value was set to be 1.1 as suggested by Duan et al. [8] and Sun et al. [40].

In this study, annual evapotranspiration (ET) was firstly estimated using both the Budyko (Equation 8) and Zhang equations (Equation 9) and, then, compared with the difference between the long-term mean annual precipitation and mean annual streamflow, which is considered as the "actual evapotranspiration" because that it is reasonable to assume that changes in soil water storage are zero and the changes in the recharge to groundwater are small over a long period of time (i.e., 5-10 years) in the catchment water balance framework [41]. We found that the annual ET calculated by Budyko equation was closer to the actual evapotranspiration. Thus, the results from Budyko equation was used in this study.

$$
\begin{gathered}
E T=\{P[1-\exp (-P E T / P)] \times P E T \times \tanh (P / P E T)\}^{0.5} \\
E T=P[1+w(P E T / P)] /[1+w(P E T / P)+P / P E T]
\end{gathered}
$$


where $\mathrm{w}$ is plant available water coefficient, which is set to be 2 given the large proportion of forest cover in study watersheds [41]. P and PET represent annual precipitation and annual potential evapotranspiration, respectively.

\section{Sensitivity-Based Method}

The variations in mean annual streamflow attributed to climate variability $\left(\Delta Q_{C}\right)$ is calculated from the changes of annual precipitation $(P)$ and potential evapotranspiration $(P E T)$ between the different phases in the sensitivity-based method as follow [42,43]:

$$
\Delta Q_{C}=\psi_{P} \Delta P+\psi_{P E T} \Delta P E T
$$

where $\triangle P$ and $\triangle P E T$ are the changes in precipitation $P$ and $P E T$ between the forest recovery period and the reference period. $\psi_{P}$ and $\psi_{P E T}$ are streamflow sensitivity coefficients to $P$ and $P E T$ as expressed below [44]:

$$
\begin{gathered}
\psi_{P}=\frac{1+2 x+3 w x}{\left(1+x+w x^{2}\right)^{2}} \\
\psi_{P E T}=-\frac{1+2 w x}{\left(1+x+w x^{2}\right)^{2}}
\end{gathered}
$$

where $\mathrm{x}$ is the mean annual index of dryness and is equal to PET/P and $\mathrm{w}$ is plant available water coefficient the same as Equation (10).

Once $\Delta Q_{C}$ was estimated, the $\Delta Q_{F}$ can be determined by the equation as follow:

$$
\Delta Q_{F}=\Delta Q-\Delta Q_{C}
$$

Time Trend Analysis Method

In the time trend analysis method, the Kendall-Theil robust line method [45] was firstly used to create a linear equation between annual streamflow and annual effective precipitation in the reference period as Equation (15), and the equation was then applied in the forest recovery period to predict annual streamflow. Thus, the difference between mean annual streamflow $\left(Q_{2}\right)$ and mean annual predicted streamflow $\left(Q_{2 P}\right)$ in the forest recovery period was considered the effects of forest recovery on annual streamflow $\left(\Delta Q_{F}\right)$, as shown in Equation (16). Once the $\Delta Q_{F}$ was estimated, the $\Delta Q_{C}$ can be determined by Equation (2).

$$
\begin{gathered}
Q_{t}=a P_{e t}+b \\
\Delta Q_{F}=Q_{2}-Q_{2 P}
\end{gathered}
$$

where $Q_{t}$ and $P_{e t}$ are annual streamflow and annual effective precipitation at the thear in the reference period, respectively, and $\mathrm{a}$ and $\mathrm{b}$ are the constants of linear equation.

\section{Results}

\subsection{Trends of Annual and Seasonal Hydrometeorological Variables}

For annual hydrometeorological data series from 1987 to 2016 (Table 2), very few significant $(p<0.05)$ trends were found, mainly on annual PET, spring flow rate, and spring and winter precipitations in XNC watershed in comparison with none significant $(p>0.05)$ trend in UTH watershed. Although there was no significant trend in annual streamflow in UTH watershed, the annual flow rate decreased by $2.0 \mathrm{~mm} /$ year vs. $1.1 \mathrm{~mm} /$ year in XNC watersheds. However, the summer streamflow in UTH watershed was characterized by an apparent decreasing pattern ( $1.88 \mathrm{~mm} /$ year $)$ comparing to the decreasing precipitation $(1.90 \mathrm{~mm} /$ year). 
Table 2. Results of Mann-Kendall trend tests on hydrometeorological variables in the UTH watershed and XNC watershed from 1987 to 2016.

\begin{tabular}{|c|c|c|c|c|c|c|c|c|c|}
\hline \multirow[b]{2}{*}{ Period } & \multirow[b]{2}{*}{ Watershed } & \multicolumn{2}{|l|}{$\mathbf{Q}$} & \multicolumn{2}{|l|}{$\mathbf{P}$} & \multicolumn{2}{|l|}{$T$} & \multicolumn{2}{|l|}{ PET } \\
\hline & & $\begin{array}{c}\text { Slope }^{1} \\
\text { (mm/year) }\end{array}$ & $p$ & $\begin{array}{c}\text { Slope } \\
\text { (mm/year) }\end{array}$ & $p$ & $\begin{array}{c}\text { Slope } \\
\left({ }^{\circ} \mathrm{C} / \text { year }\right)\end{array}$ & $p$ & $\begin{array}{c}\text { Slope } \\
\text { (mm/year) }\end{array}$ & $p$ \\
\hline \multirow{2}{*}{ Annual } & UTH & -2.0 & 0.26 & -1.2 & 0.48 & 0.00 & 0.93 & 0.58 & 0.15 \\
\hline & XNC & -1.1 & 0.67 & 0.25 & 0.92 & 0.00 & 0.75 & $0.59 *$ & 0.01 \\
\hline \multirow{2}{*}{ Spring } & UTH & 0.35 & 0.55 & 1.03 & 0.11 & 0.02 & 0.31 & 0.30 & 0.11 \\
\hline & XNC & 1.09 * & 0.02 & 2.36 * & 0.01 & 0.02 & 0.33 & 0.25 & 0.17 \\
\hline \multirow{2}{*}{ Summer } & UTH & -1.88 & 0.32 & -1.90 & 0.32 & 0.02 & 0.16 & 0.58 & 0.08 \\
\hline & XNC & -0.04 & 1.00 & 0.31 & 0.97 & 0.03 & 0.07 & 0.47 & 0.11 \\
\hline \multirow{2}{*}{ Autumn } & UTH & -0.29 & 0.62 & -0.16 & 0.86 & -0.02 & 0.41 & 0.00 & 0.94 \\
\hline & XNC & -0.63 & 0.50 & -1.67 & 0.18 & 0.01 & 0.72 & 0.10 & 0.27 \\
\hline \multirow{2}{*}{ Winter } & UTH & -0.04 & 0.44 & -0.2 & 0.36 & -0.03 & 0.25 & -0.04 & 0.83 \\
\hline & XNC & -0.03 & 0.86 & $1.18 *$ & 0.02 & -0.04 & 0.38 & -0.11 & 0.55 \\
\hline
\end{tabular}

* values indicate the statistical significance at the level of $0.05 .{ }^{1}$ The Slope was estimated using the nonparametric median-based slope method [33,34]. Q, streamflow; $P$, precipitation; T, mean annual air temperature; PET, potential evapotranspiration ET, evapotranspiration; Spring, April to May; Summer, June to August; Autumn, September to October; Winter, November to March.

\subsection{Cross-Correlations between Forest Cover and Hydrological Variables}

Cross-correlation analysis suggests that annual streamflow in UTH and XNC watersheds was significantly negatively correlated with annual forest cover from 1987 to 2016 (Table 3) except for winter season regardless of watersheds. However, there is a significantly positive correction between the streamflow and forest cover during spring season for both watersheds. In addition, the lags between hydrological variables and forest cover varied with watershed, 4-10 years for UTH and 0-5 years for XNC watersheds, respectively.

Table 3. Cross-correlations between forest cover and hydrological variables.

\begin{tabular}{lcccccccc}
\hline & \multicolumn{3}{c}{ Forest Cover of UTH (1,1,1) } & \multicolumn{3}{c}{ Forest Cover of XNC (1,1,1) } \\
\cline { 2 - 9 } Variables & $\begin{array}{c}\text { ARIMA } \\
\text { Model }\end{array}$ & $\begin{array}{c}\text { Cross-Correlation } \\
\text { Coefficient }\end{array}$ & $p$ & Lag & $\begin{array}{c}\text { ARIMA } \\
\text { Model }\end{array}$ & $\begin{array}{c}\text { Cross-Correlation } \\
\text { Coefficient }\end{array}$ & $p$ & Lag \\
\hline Annual & $(1,0,0)$ & $-0.51^{* *}$ & 0.005 & 9 & $(1,0,0)$ & $-0.54^{* *}$ & 0.001 & 5 \\
Spring & $(1,0,0)$ & $0.46^{*}$ & 0.019 & 4 & $(0,0,1)$ & $0.41^{*}$ & 0.026 & 0 \\
Summer & $(0,0,1)$ & $-0.40^{*}$ & 0.038 & 10 & $(1,0,0)$ & $-0.46^{* *}$ & 0.007 & 5 \\
Autumn & $(1,0,1)$ & $-0.41^{*}$ & 0.017 & 9 & $(0,0,1)$ & $-0.40^{*}$ & 0.025 & 5 \\
Winter & $(1,0,0)$ & -0.28 & 0.170 & 5 & $(1,0,0)$ & 0.16 & 0.404 & 0 \\
\hline
\end{tabular}

${ }^{1}$ ARIMA is autoregressive integrated moving average. ${ }^{* *}$ values indicate the statistical significance at the level of 0.01 . * the statistical significance at the level of 0.05 .

\subsection{Separating the Relative Contributions of Forest Recovery and Climate Variability to the Changes in Annual} Streamflow

Break points were detected in the modified double mass curves (MDMCs) in 2003 and 2001 for UTH and XNC watersheds (Figure 4), respectively. The fitted interrupted ARIMA model of the MDMCs slopes further confirmed that the break points were statistically significant $(p<0.05$, Table 4$)$. Thus, the entire study period (1987-2016) was then identified as two periods: the reference period (1987 to 2002 for UTH and 1987 to 2000 for XNC) and the forest recovery period (2003 to 2016 for UTH and 2001 to 2016 for XNC). 

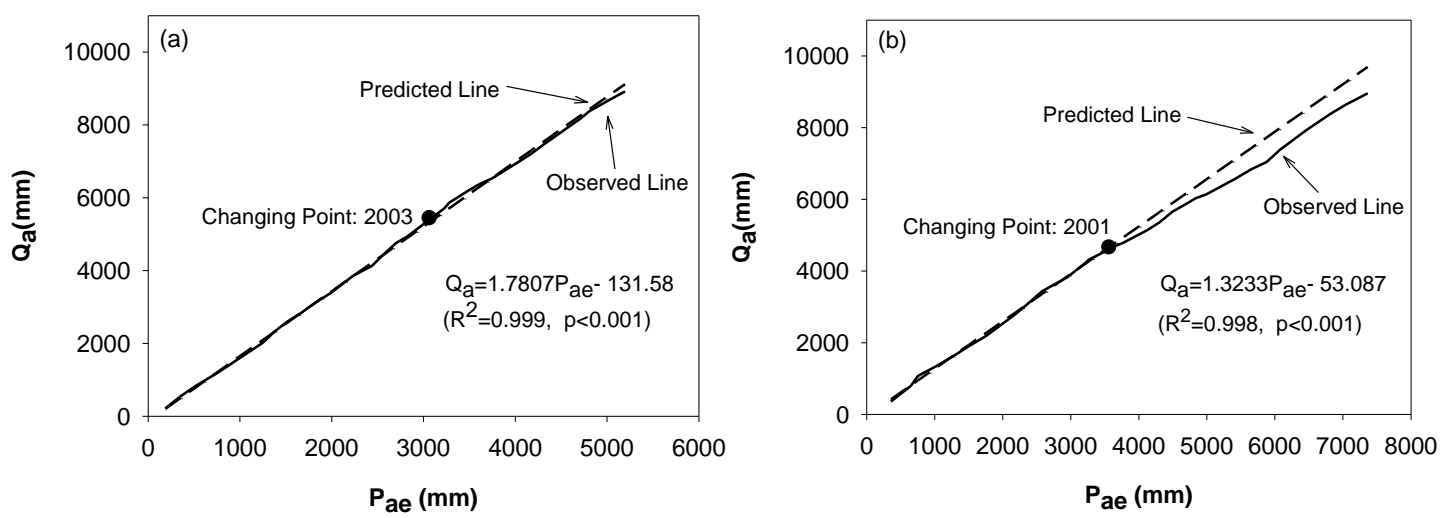

Figure 4. Double mass curve of accumulated annual streamflow $\left(Q_{a}\right)$ and accumulated annual effective precipitation $\left(P_{a e}\right)$ for: UTH (a); and XNC (b).

Table 4. Interrupted ARIMA models for slopes of MDMC in Figure 4.

\begin{tabular}{cccc}
\hline Model Input & Model Structure & \multicolumn{2}{c}{ Parameter Estimation } \\
$\mathbf{q ( 1 )} \mathbf{1}^{\mathbf{1}}$ & $\mathbf{\Omega}^{\mathbf{2}}$ \\
\hline $\begin{array}{c}\text { Slope of } \mathrm{MDMC}^{3} \text { of UTH in } \\
\text { Figure 4a }\end{array}$ & $\begin{array}{c}\text { Interrupted ARIMA: }(0,0,1), \\
\text { intervention at year 2003 }\end{array}$ & $-0.73(p<0.05)$ & $0.52(p<0.05)$ \\
Slope of MDMC of XNC in & $\begin{array}{c}\text { Interrupted ARIMA: }(0,0,1), \\
\text { Figure } 4 \mathrm{~b}\end{array}$ & $-0.76(p<0.05)$ & $0.73(p<0.05)$ \\
\hline
\end{tabular}

${ }^{1} \mathrm{q}$ is moving average parameter, ${ }^{2} \Omega$ is intervention parameter for abrupt permanent intervention type,${ }^{3}$ is modified double mass curve.

Forest recovery decreased the mean annual streamflow by 16.9 and $43.4 \mathrm{~mm}$ from the reference period in UTH and XNC watersheds, respectively, the corresponding relative contributions to the changes in mean annual streamflow being $70.6 \%$ and $93.3 \%$, respectively. By contrast, climate variability induced reductions in mean annual streamflow were 7.0 and $3.1 \mathrm{~mm}$, respectively, with corresponding relative contributions being $29.4 \%$ and $6.7 \%$, respectively.

The results of the sensitivity-based method (Table 5) indicate that climate variability decreased mean annual streamflow by 8.8 and $7.5 \mathrm{~mm}$ from the reference period to the forest recovery period in $\mathrm{UTH}$ and XNC watersheds, respectively, in comparison with the reduction of precipitation $(-11.3 \mathrm{~mm}$ for UTH and $-7.7 \mathrm{~mm}$ for XNC) and the increase of PET (7.0 $\mathrm{mm}$ for UTH and $7.9 \mathrm{~mm}$ for XNC). Thus, the contributions of forest recovery to the changes in mean annual streamflow were determined as -15.1 and $-39.0 \mathrm{~mm}$ in UTH and XNC watersheds, respectively (Table 5).

Table 5. The relative contributions of climate variability and forest recovery calculated by the sensitivity-based method.

\begin{tabular}{|c|c|c|c|c|c|c|c|c|c|c|}
\hline Watershed & Sub-Periods & $\begin{array}{c}P \\
(\mathrm{~mm})\end{array}$ & $\begin{array}{c}P E T \\
(\mathrm{~mm})\end{array}$ & $\begin{array}{c}\Delta P \\
(\mathrm{~mm})\end{array}$ & $\begin{array}{l}\triangle P E T \\
(\mathrm{~mm})\end{array}$ & $\beta$ & $\gamma$ & $\begin{array}{c}\Delta Q \\
(\mathrm{~mm})\end{array}$ & $\begin{array}{c}\Delta Q_{C} \\
(\mathrm{~mm})\end{array}$ & $\begin{array}{c}\Delta Q_{F} \\
(\mathrm{~mm})\end{array}$ \\
\hline \multirow{4}{*}{ UTH } & 1987-2002 & 540.7 & 517.3 & \multirow{4}{*}{-11.3} & \multirow{4}{*}{7.0} & \multirow{4}{*}{0.58} & \multirow{3}{*}{-0.33} & \multirow{3}{*}{-23.9} & \multirow{3}{*}{-8.8} & \multirow{3}{*}{-15.1} \\
\hline & & & & & & & & & & \\
\hline & $2003-2016$ & 529.5 & 524.3 & & & & & & & \\
\hline & 1987-2000 & 715.9 & 652.8 & & & & \multirow{3}{*}{-0.36} & \multirow{3}{*}{-46.5} & \multirow{3}{*}{-7.5} & \multirow{3}{*}{-39.0} \\
\hline \multirow[t]{2}{*}{$\mathrm{XNC}$} & & & & \multirow[t]{2}{*}{-7.7} & \multirow[t]{2}{*}{7.9} & \multirow[t]{2}{*}{0.60} & & & & \\
\hline & 2001-2016 & 708.2 & 660.7 & & & & & & & \\
\hline
\end{tabular}

The results of time trend analysis method shown in Figure 5 indicated that the mean annual observed streamflow was 14.1 and $39.8 \mathrm{~mm}$ lower than the predicted values in forest recovery period 
in UTH and XNC watersheds, respectively. Thus, the relative contributions of climate variability were calculated as the difference between the total changes in mean annual streamflow and the changes attributed to forest recovery (Equation 1), and these values were -9.8 and $-6.9 \mathrm{~mm}$ for UTH and XNC watersheds, respectively.
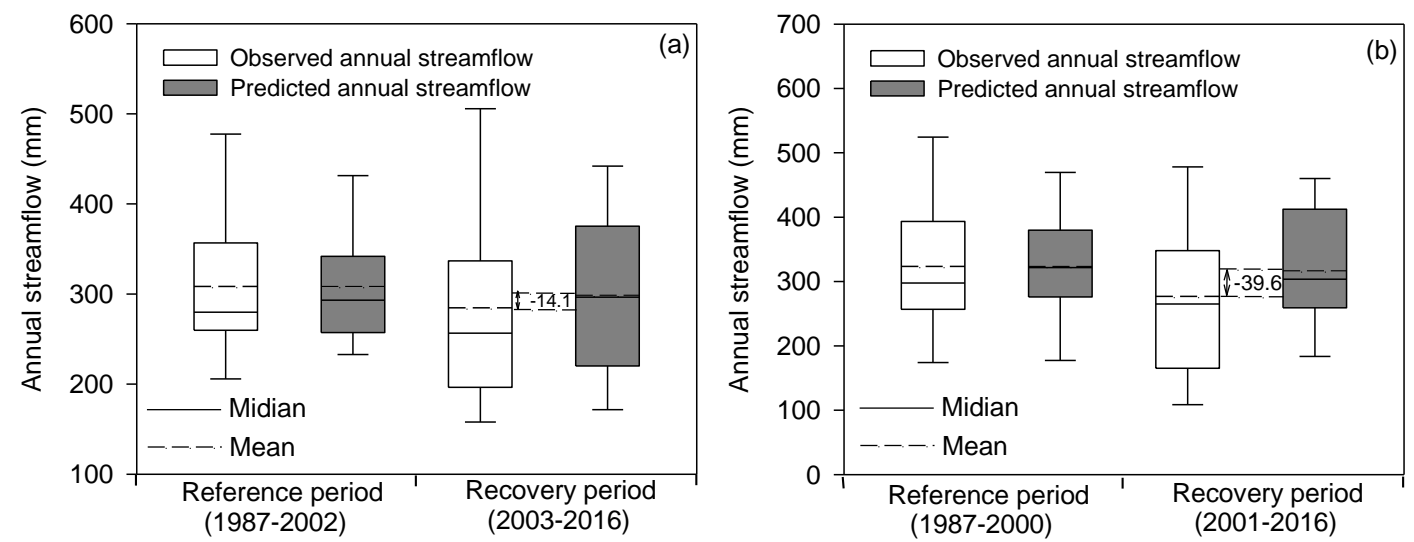

Figure 5. The box plot of observed and predicted annual streamflow calculated by time trend analysis method in: XNC (a); and UTH (b).

The total changes in mean annual streamflow $(\Delta Q)$ and the associated components $\left(\Delta Q_{C}\right.$ and $\left.\Delta Q_{F}\right)$ calculated by three independent methods in two watersheds are summarized in Table 6 . The results from three methods produced similar results. The relative contributions of forest recovery to the reductions of mean annual streamflow were $-15.4 \mathrm{~mm}(64.3 \%)$ and $-40.7 \mathrm{~mm}(87.4 \%)$ in UTH and XNC watersheds, respectively, while the relative contributions of climate variability were $-8.5 \mathrm{~mm}$ $(35.7 \%)$ and $-7.2 \mathrm{~mm}(12.6 \%)$, respectively. Overall, the impacts of forest recovery on long-term annual streamflow variations were much higher than those from climate variability, which indicated that the variations of water yield in the UTH and XNC watersheds were mainly controlled by forest recovery in the past three decades.

Table 6. Long-term annual streamflow changes and their components in UTH and XNC watersheds.

\begin{tabular}{|c|c|c|c|c|c|c|c|c|c|c|}
\hline \multirow{3}{*}{ Method } & \multicolumn{5}{|c|}{ UTH (from 1987-2002 to 2003-2016) } & \multicolumn{5}{|c|}{ XNC (from 1987-2000 to 2001-2016) } \\
\hline & \multicolumn{3}{|c|}{$\begin{array}{l}\text { Changes in Streamflow } \\
(\mathrm{mm})\end{array}$} & \multicolumn{2}{|c|}{$\begin{array}{c}\text { Relative } \\
\text { Contributions (\%) }\end{array}$} & \multicolumn{3}{|c|}{$\begin{array}{l}\text { Changes in Streamflow } \\
(\mathrm{mm})\end{array}$} & \multicolumn{2}{|c|}{$\begin{array}{c}\text { Relative } \\
\text { Contributions (\%) }\end{array}$} \\
\hline & $\Delta Q$ & $\Delta Q_{C}$ & $\Delta Q_{F}$ & Climate & Forest & $\Delta Q$ & $\Delta Q_{C}$ & $\Delta Q_{F}$ & Climate & Forest \\
\hline MDMC $^{1}$ & & -7.0 & -16.9 & 2 & 70.6 & & -3.1 & -43.4 & 6.7 & 93.3 \\
\hline TRA $^{2}$ & & -9.8 & -14.1 & 40.9 & 59.1 & & -6.9 & -39.6 & 14.9 & 85.1 \\
\hline $\mathrm{SBM}^{3}$ & -23.9 & -8.8 & -15.1 & 36.8 & 63.2 & 6.5 & -7.5 & -39.0 & 16.1 & 83.9 \\
\hline Average & & -8.5 & -15.4 & 35.7 & 64.3 & & -7.2 & -40.7 & 12.6 & 87.4 \\
\hline
\end{tabular}

${ }^{1}$ MDMC is Modified Double Mass Curve method, ${ }^{2}$ TRA is Time Trend Analysis method and ${ }^{3}$ SBM is Sensitivity-based Method.

\section{Discussion}

\subsection{The Effects of Forest Recovery on Water Yield}

Our results indicated that the forest recovery was the dominant driver of the reduction in mean annual water yield, -15.4 and $-40.7 \mathrm{~mm}$ for UTH and XNC watersheds, respectively. The negative effects of reforestation on water yield are consistent with many study findings in other regions. For instance, Liu et al. [46] found that the reforestation in the Meijiang watershed $\left(6983 \mathrm{~km}^{2}\right)$ covered by subtropical evergreen broad-leaved forest caused an average annual streamflow reduction of $51 \mathrm{~mm}$ in the reforestation period (1985-2006). Tuteja et al. [47] found that annual runoff reductions from 
pine plantations ranged from 22 to $52 \mathrm{~mm}$ /year in the different subcatchments of a large catchment in southeastern Australia. The negative effects of reforestation on water yield are possibly due to the increase in evapotranspiration resulting from vegetation development (e.g., increasing leaf areas and root systems) [46]. Forest recovery can also improve soil conditions and enhance the water storage in aquifers [48]. Such changes in hydrological processes consequently result in the reduction of water yield observed from stream. Such reductions in annual water yield caused by reforestation were also reviewed on 73 watershed studies across the globe by Li et al. [5].

Although the forest recovery in this study showed similar impacts on water yield to the previous studies, the sensitivity of annual water yield to forest cover change in these study watersheds is much greater than that in other studies. Our results indicated that $1 \%$ forest cover increase resulted in $0.7 \%$ of reduction in annual water yield in the boreal coniferous forest watershed (UTH), while $1.8 \%$ of reduction in the mixed coniferous and broadleaved forest watershed (XNC). After examining 61 large $\left(>1000 \mathrm{~km}^{2}\right)$ watersheds across the world, Zhang et al. [4] found that in large mixed forest dominated watersheds, $1 \%$ forest cover change can result in $0.80 \%$ change in annual runoff vs. $0.24 \%$ for large coniferous forest dominated watersheds. The difference in the sensitivity of annual water yield response to forest cover change between our study and the study of Zhang et al. [4] may be due to the differences in climatic regimes. The watersheds in this study are located in the high latitude cold region of Northeast China, where the climate is characterized by a typical continental monsoon climate. Approximately $85 \%$ of precipitation occurring as rain during the growing season may have been evapotranspired and consequently enhance the negative effects of forest recovery on water yield, as reported by Zhang, Dawes and Walker [41]. This conclusion can be also reinforced by the fact that the total decreases in streamflow during growing season (from June to October) accounted for $84.4 \%$ and $77.9 \%$ of the total reductions of annual water yield in UTH and XNC watersheds, respectively. Thus, it is safe to say that the impacts of forest recovery on long-term water yield are closely related to its impacts during wet seasons (i.e., summer and autumn in study watersheds), a good consistence with other summer dominant rainfall regions as well [49-51]. In addition, the different contribution rates of forest recovery to streamflow change between two watersheds in our study may also be partially related to the water condition difference (Table 1).

\subsection{The Effects of Forest Type and Topography on the Response Intensity of Water Yield to Forest Recovery}

Our results indicated that 1\% forest cover increase can result in $1.8 \%$ reduction in annual streamflow in the mixed coniferous and broadleaved forest watershed (XNC) and $0.7 \%$ in the boreal coniferous forest watershed (UTH). The distinct response between two watersheds may be because of the difference in forest types, topography and climate regimes. Firstly, forest type can significantly affect the hydrological response to forest recovery [52]. For instance, in the Puget Sound basin covered by mixed coniferous and deciduous forest in northwestern Washington, USA, the annual streamflow response to forest recovery was estimated as 6.8\% [53]. However, in the large boreal coniferous forest watersheds in Northeastern Ontario, Canada, there was no definitive changes in annual water yield with forest cover ranging from $8.6 \%$ to $25.2 \%$ [54]. Meanwhile, Zhang et al. [4] found that the response intensity of annual streamflow to forest cover change in large mixed forest watersheds was approximately three time of that in large coniferous forest watersheds based on the data from 61 large watersheds across the world. These previous studies and ours all suggested that large boreal coniferous forest watersheds may have the relative higher hydrological elasticity in response to forest cover change than the large mixed forest watersheds. In this study, relatively lower transpiration of boreal coniferous forest than the broadleaved forest in the cold regions [55,56] may lead to smaller changes of evapotranspiration in response to forest recovery. In addition, the different mean annual rainfall between two sites in this study can have a strong influence on the change in annual water yield with forest cover change [41,57]. Bosch and Hewlett [58] and Farley, Jobbágy and Jackson [52] found that vegetation change has the largest absolute impacts on water yield in high-rainfall areas. This is confirmed by our findings that the XNC watershed has a higher magnitude of rainfall than 
UTH watershed, therefore, a greater response intensity of annual streamflow to forest recovery as well. Additionally, the boreal forest watershed (UTH) has a shorter and cooler growing season than the mixed forest watershed (XNC) because of the higher latitude, which consequently results in a lower evapotranspiration in the watershed. All these different characteristics of forest types and interactions with climate in boreal forest watershed attenuate the strength of the impacts of forest cover change on long-term water yield. Nevertheless, more case and modeling studies can definitely help to examine how forest types affect water yield in large forested watersheds.

Topography also plays a critical role in determining hydrological responses to reforestation [59]. As shown in Table 7, the UTH watershed is characterized by a more gently topography than XNC watershed. XNC watershed has $68 \%$ of the watershed area covered by the slopes greater than $15^{\circ}$ vs. $44 \%$ in UTH watershed, which may have made the UTH a greater hydrological elasticity in response to forest recovery. Although few studies have been dedicated to detect the impacts of different topography on annual water yield, the studies on the effects of topography on specific flow variable [60] can help understand how different topography affects annual water yield. Liu et al. [61] found that hydrological recovery is limited and slower with reforestation in the steeper watershed. Li et al. [62] also found that the topography indices including perimeter, slope length factor, surface area, openness, and topographic characteristic index can be responsive to the streamflow change, in particular, to the low flow variables in snow-dominated regions in the Southern Interior of British Columbia, Canada. This may be because a watershed with gentler topography would likely have a higher water retention ability due to longer flow paths and residence time and consequently enhance the hydrological elasticity $[63,64]$. Thus, the different response intensity of annual water yield to forest recovery between two study watersheds was partly explained by the hydrological elasticity differentiated by topography in the two watersheds.

Table 7. Averaged slopes in two studied watersheds.

\begin{tabular}{ccccccc}
\hline \multirow{2}{*}{ Watershed } & \multicolumn{7}{c}{ Percentage of Watershed Area (\%) } \\
\cline { 2 - 7 } & Slope $>\mathbf{4 0}^{\circ}$ & $\mathbf{2 0 - 4 0 ^ { \circ }}$ & $\mathbf{1 5 - 2 0}^{\circ}$ & $\mathbf{1 0}^{-15^{\circ}}$ & $\mathbf{5 - 1 0 ^ { \circ }}$ & $<5^{\circ}$ \\
\hline UTH & 0.7 & 22.0 & 19.6 & 30.4 & 3.8 & 23.4 \\
XNC & 0.5 & 33.4 & 34.0 & 4.6 & 4.6 & 23.0 \\
\hline
\end{tabular}

Our results of cross-correlations between forest cover and annual flow indicated that there were nine- and five-year lags between forest cover and annual water yield in the UTH and XNC watersheds, respectively (Table 3). Such lagging effects were mainly due to the delayed hydrological responses to forest recovery, because forest recovery may take years or decades to reach a new hydrological equilibrium [65], particularly in the boreal forest that takes much longer time to recover after disturbance than other forest ecosystem in warmer regions [66]. On the other hand, the longer lags in the boreal coniferous forest watershed (UTH) could also partly be due to the stronger hydrological elasticity discussed above.

\subsection{The Relative Contributions of Forest Recovery and Climate Variability to Water Yield Variations}

Our results from three independent methods indicated that forest recovery was the dominate driver with the relative contributions to the changes in water yield being $64.3 \%$ and $87.4 \%$ in the UTH and XNC watersheds, respectively. Consistent results were also found in other regions. For instance, Liu et al. [67] studied in the middle and lower reaches of the Yellow River, China, vegetation changes were the main cause for triggering annual runoff changes, which account for approximately $80 \%$ from baseline period to changeable period. Similar findings were also reported for the headwaters of the Yellow River basin by Zheng et al. [68]. By contrast, many more studies conclude climate variability has a similar or greater strength of impacts on water yield compared to forest cover change. For instance, the equal hydrological impacts of forest cover change and climate variability were found 
in large forested watersheds in the central interior of British Columbia, Canada [9], in the the Upper Minjiang River of Yangtze River basin, China [69] and in the upper reach of the Poyang Lake basin, China [46]. Li et al. [10] found that the relative contribution of forest disturbance was only $27 \%$ in the Upper Similkameen River watershed situated between Canada and the USA. Similarly, Shi et al. [70] found that the streamflow was more sensitive to climate variability than land cover change in the Upstream of Huai River, China. The relative contributions of forest cover change and climate variability are largely dependent on their magnitude and the characteristics of watersheds. More case studies would help explore how forest cover change and climate variability interactively affect hydrology in large watersheds.

\subsection{Implications and Uncertainty}

Boreal coniferous forest and boreal/temperate transition mixed coniferous and broadleaved forest are both located in the remote cold region of Northeast China, where the natural forest experienced prolonged timber harvesting during the 1960s to late 1990s before Natural Forest Protection Project was carried out, and experienced a recovery period in the past three decades. Since 2016, timber harvesting has been completely banned in the natural forest. Although such forest management policies have made forest ecosystems well restored, the potential changes in water resources shrink caused by the increasing forest cover had been ignored. Our results indicated that the mean annual water yield decreased by $8.0 \%$ and $15.6 \%$ due to the increases of $11.6 \%$ and $8.7 \%$ in forest cover in UTH and XNC watersheds, respectively, in the past three decades. Such great sensitivity of annual water yield to the increases in forest cover should be a great concern, especially in the region covered by mixed coniferous and broadleaved forest, as the downstream of this region is one of the most important crop-producing areas in China. The reduction of annual water yield in the streams may cause a shortage of water for irrigation in downstream. Thus, the policies of forest management should meet the water level that can maintain aquatic functions and ecosystem integrity as well as ensure the water supply for irrigation in downstream area, which need more future quantitative studies to provide more information. For the boreal forest watershed, the reduction of water yield may not be a serious issue due to the relatively low demands of water supply. Nevertheless, the reduction in water flow caused by forest cover change require further investigation, because they are critical for maintaining the dynamics of in-channel and floodplain habitats that play a critical role in sustaining native biodiversity and ecosystem integrity in rivers [71,72], which can be more important than water supply in the boreal forest region in China.

There are several uncertainties in this study. Firstly, although three independent methods were used to quantify the relative contribution of forest recovery to annual water yield and achieved relatively consistent results, the variations of hydrological processes over study period were rarely understood. For example, annual effective precipitation was used to minimize the impacts of annual precipitation on streamflow in the methods of MDMC and time trend analysis method. However, the changes in intra-annual [73] or seasonal climate patterns [74] can significantly affect inter-annual water yield. In addition, reforestation can potentially more or less increase regional precipitation and water availability, and consequently compensate water loss by increased forest evapotranspiration $[1,75]$. However, these meteorological and hydrological variations were not considered in our quantitative methods. Second, the PET values were estimated by the Hamon method, which is a widely used temperature-based method. However, relative humidity, wind speed, and solar radiation could be affected by reforestation and, in turn, affect the PET [76-78]. These factors were not included in the PET estimations in this study. Thirdly, permafrost thaw and seasonal frost changes caused by climate warming can happen even in a period with the relative stable temperature $[79,80]$, and consequently affect the long-term regional water yield [8,25,81]. Although the period 1987 to 2016 had a relative stable temperature, many studies demonstrated that there was a significant warming trend in Northeast China in the past half century $[82,83]$, thus climate change consideration would be necessary for a longer study. In particular, when permafrost warming or frozen ground degradation has already been observed in this region $[84,85]$, which may completely change the response pattern of streamflow to 
forest recover. However, the impacts of permafrost thaw and frozen ground degradation on water yield were not considered in this study, which need future more process-based studies to investigate.

\section{Conclusions}

Based on data from two monitored large watersheds, this study proved that forest recovery was the dominant driver to the reduction of mean annual water yield, while the impacts of climate variability were relatively low in the two large forested watersheds in cold region of Northeast China during the past three decades. The relative contributions of forest recovery to the reductions in mean annual water yield were $64.3 \%(15.4 \mathrm{~mm})$ and $87.4 \%(40.7 \mathrm{~mm})$ in UTH and XNC watersheds, respectively, while the rest of the reductions in mean annual water yield were attributed to climate variability. We also found that the response intensity of annual water yield response to increasing forest cover in mixed coniferous and broadleaved forest watershed (XNC) was much greater than that in boreal coniferous forest watershed (UTH). It is well known that forest can conserve water and soil resources, therefore, reduce streamflow. However, the reduction of streamflow responding to the increasing vegetation recover may pose an additional issue to the downstream water supply for irrigating agricultural land. A proper trade-off between forest resource protection and proper downstream irrigation water supply must be sought in the future for an effective ecosystem management. These findings are of great importance for both water resource and forest management in large forested watersheds in Northeast China and similar watersheds in other cold regions.

Author Contributions: L.D and T.C. conceived and designed the research themes; L.D. wrote the paper. T.C. contributed to data preparation.

Funding: This research was funded by the National Science Foundation of China (Grant No. 31770488), and the CFERN \& BEIJING TECHNO SOLUTIONS Award Funds on excellent academic achievements.

Acknowledgments: We acknowledge the financial support by the National Science Foundation of China (Grant No. 31770488). This work is also supported by CFERN \& BEIJING TECHNO SOLUTIONS Award Funds on excellent academic achievements. We thank Zisheng Xing for improving the English of this article.

Conflicts of Interest: The authors declare no conflict of interest.

\section{References}

1. Li, Y.; Piao, S.; Li, L.Z.X.; Chen, A.; Wang, X.; Ciais, P.; Huang, L.; Lian, X.; Peng, S.; Zeng, Z. Divergent hydrological response to large-scale afforestation and vegetation greening in China. Sci. Adv. 2018, 4, eaar4182. [CrossRef] [PubMed]

2. Zhang, S.; Yang, D.; Yang, Y.; Piao, S.; Yang, H.; Lei, H.; Fu, B. Excessive afforestation and soil drying on China's loess plateau. J. Geophys. Res. Biogeosci. 2018, 123, 923-935. [CrossRef]

3. Qiu, J. China drought highlights future climate threats. Nature 2010, 465, 142-143. [CrossRef] [PubMed]

4. Zhang, M.; Liu, N.; Harper, R.; Li, Q.; Liu, K.; Wei, X.; Ning, D.; Hou, Y.; Liu, S. A global review on hydrological responses to forest change across multiple spatial scales: Importance of scale, climate, forest type and hydrological regime. J. Hydrol. 2017, 546, 44-59. [CrossRef]

5. Li, Q.; Wei, X.; Zhang, M.; Liu, W.; Fan, H.; Zhou, G.; Giles-Hansen, K.; Liu, S.; Wang, Y. Forest cover change and water yield in large forested watersheds: A global synthetic assessment. Ecohydrology 2017, 10, e1838. [CrossRef]

6. Kiely, G.; Nadezhdina, N.; Zappa, M. The response of the water fluxes of the boreal forest region at the volga's source area to climatic and land-use changes. Phys. Chem. Earth 2002, 27, 675-690.

7. Wattenbach, M.; Zebisch, M.; Hattermann, F.; Gottschalk, P.; Goemann, H.; Kreins, P.; Badeck, F.; Lasch, P.; Suckow, F.; Wechsung, F. Hydrological impact assessment of afforestation and change in tree-species composition-A regional case study for the federal state of Brandenburg (Germany). J. Hydrol. 2007, 346, 1-17. [CrossRef]

8. Duan, L.L.; Man, X.L.; Kurylyk, B.L.; Cai, T.J.; Li, Q. Distinguishing streamflow trends caused by changes in climate, forest cover, and permafrost in a large watershed in northeastern China. Hydrol. Process. 2017, 31, 1938-1951. [CrossRef] 
9. Wei, X.H.; Zhang, M.F. Quantifying streamflow change caused by forest disturbance at a large spatial scale: A single watershed study. Water Resour. Res. 2010, 46. [CrossRef]

10. Li, Q.; Wei, X.; Zhang, M.; Liu, W.; Giles-Hansen, K.; Wang, Y. The cumulative effects of forest disturbance and climate variability on streamflow components in a large forest-dominated watershed. J. Hydrol. 2017, 557, 448-459. [CrossRef]

11. Wei, X.; Li, Q.; Zhang, M.; Giles-Hansen, K.; Liu, W.; Fan, H.; Wang, Y.; Zhou, G.; Piao, S.; Liu, S. Vegetation cover-Another dominant factor in determining global water resources in forested regions. Glob. Chang. Biol. 2017, 24, 786-795. [CrossRef] [PubMed]

12. Zhang, M.; Wei, X. The effects of cumulative forest disturbance on streamflow in a large watershed in the central interior of British Columbia, Canada. Hydrol. Earth Syst. Sci. 2012, 16, 2021-2034. [CrossRef]

13. Zhao, F.F.; Zhang, L.; Xu, Z.X.; Scott, D.F. Evaluation of methods for estimating the effects of vegetation change and climate variability on streamflow. Water Resour. Res. 2010, 46. [CrossRef]

14. Zhang, S.; Yang, Y.; Mcvicar, T.R.; Yang, D. An analytical solution for the impact of vegetation changes on hydrological partitioning within the budyko framework. Water Resour. Res. 2018, 54, 519-537. [CrossRef]

15. Peña-Arancibia, J.L.; Dijk, A.I.J.M.V.; Guerschman, J.P.; Mulligan, M.; Bruijnzeel, L.A.; Mcvicar, T.R. Detecting changes in streamflow after partial woodland clearing in two large catchments in the seasonal tropics. J. Hydrol. 2012, 416, 60-71. [CrossRef]

16. Beck, H.E.; Bruijnzeel, L.A.; Dijk, A.I.J.M.V.; Mcvicar, T.R. The impact of forest regeneration on streamflow in 12 meso-scale humid tropical catchments. Hydrol. Earth Syst. Sci. 2013, 17, 2613-2635. [CrossRef]

17. Wei, X.H.; Liu, W.F.; Zhou, P.C. Quantifying the relative contributions of forest change and climatic variability to hydrology in large watersheds: A critical review of research methods. Water 2013, 5, 728-746. [CrossRef]

18. Liu, Z.; Yang, J.; Chang, Y.; Weisberg, P.J.; He, H.S. Spatial patterns and drivers of fire occurrence and its future trend under climate change in a boreal forest of northeast china. Glob. Chang. Biol. 2012, 18, 2041-2056. [CrossRef]

19. Chen, X. Modeling the effects of global climatic change at the ecotone of boreal larch forest and temperate forest in northeast china. Clim. Change 2002, 55, 77-97. [CrossRef]

20. Liu, J.; Zhang, Z.; Xu, X.; Kuang, W.; Zhou, W.; Zhang, S.; Li, R.; Yan, C.; Yu, D.; Wu, S. Spatial patterns and driving forces of land use change in china during the early 21st century. J. Geog. Sci. 2010, 20, 483-494. [CrossRef]

21. Brown, J.; Ferrians Jr, O.; Heginbottom, J.; Melnikov, E. Circum-Arctic Map of Permafrost and Ground-Ice Conditions, Version 2; NSIDC: National Snow and Ice Data Center: Boulder, CO, USA, 2002.

22. Serreze, M.; Walsh, J.; Chapin Iii, F.; Osterkamp, T.; Dyurgerov, M.; Romanovsky, V.; Oechel, W.; Morison, J.; Zhang, T.; Barry, R. Observational evidence of recent change in the northern high-latitude environment. Clim. Change 2000, 46, 159-207. [CrossRef]

23. Group, M.I.E.W.; Pepin, N.; Bradley, R.S.; Diaz, H.F.; Baraer, M.; Caceres, E.B.; Forsythe, N.; Fowler, H.; Greenwood, G.; Hashmi, M.Z. Elevation-dependent warming in mountain regions of the world. Nat. Clim. Chang. 2015, 5, 424-430.

24. Woo, M.K.; Kane, D.L.; Carey, S.K.; Yang, D.Q. Progress in permafrost hydrology in the new millennium. Permafr. Periglac. Process. 2008, 19, 237-254. [CrossRef]

25. Walvoord, M.A.; Kurylyk, B.L. Hydrologic impacts of thawing permafrost-a review. Vadose Zone J. $2016,15$. [CrossRef]

26. Duan, L.; Man, X.; Kurylyk, B.L.; Cai, T. Increasing winter baseflow in response to permafrost thaw and precipitation regime shifts in northeastern China. Water 2017, 9, 25. [CrossRef]

27. Yao, Y.; Cai, T.; Ju, C.; He, C. Effect of reforestation on annual water yield in a large watershed in northeast China. J. For. Res. 2015, 26, 697-702. [CrossRef]

28. Pettitt, A. A non-parametric approach to the change-point problem. Applied Statistics 1979, 28, $126-135$. [CrossRef]

29. Yue, S.; Pilon, P.; Cavadias, G. Power of the Mann-Kendall and spearman's rho tests for detecting monotonic trends in hydrological series. J. Hydrol. 2002, 259, 254-271. [CrossRef]

30. Shadmani, M.; Marofi, S.; Roknian, M. Trend analysis in reference evapotranspiration using mann-kendall and spearman's rho tests in arid regions of Iran. Water Resour. Manag. 2012, 26, 211-224. [CrossRef]

31. Mann, H.B. Nonparametric tests against trend. Econometrica J. Econom. Soc. 1945, 13, 245-259. [CrossRef]

32. Kendall, M.G. Rank Correlation Measures; Charles Griffin: London, UK, 1975; p. 202. 
33. Sen, P.K. Estimates of the regression coefficient based on Kendall's tau. J. Am. Stat. Assoc. 1968, 63, 1379-1389. [CrossRef]

34. Hirsch, R.M.; Slack, J.R.; Smith, R.A. Techniques of trend analysis for monthly water-quality data. Water Resour. Res. 1982, 18, 107-121. [CrossRef]

35. Box, G.E.; Jenkins, G.M. Time series analysis: Forecasting and control. In Holden-Day Series in Time Series Analysis; Holden-Day: San Francisco, CA, USA, 1976.

36. Jassby, A.D.; Powell, T.M. Detecting changes in ecological time-series. Ecology 1990, 71, 2044-2052. [CrossRef]

37. Zhou, G.Y.; Wei, X.H.; Chen, X.Z.; Zhou, P.; Liu, X.D.; Xiao, Y.; Sun, G.; Scott, D.F.; Zhou, S.Y.D.; Han, L.S.; et al. Global pattern for the effect of climate and land cover on water yield. Nat. Commun. 2015, 6, 5918. [CrossRef] [PubMed]

38. Vörösmarty, C.J.; Federer, C.A.; Schloss, A.L. Potential evaporation functions compared on us watersheds: Possible implications for global-scale water balance and terrestrial ecosystem modeling. J. Hydrol. 1998, 207, 147-169. [CrossRef]

39. Pyzoha, J.E.; Callahan, T.J.; Sun, G.; Trettin, C.C.; Miwa, M. A conceptual hydrologic model for a forested Carolina bay depressional wetland on the coastal plain of south Carolina, USA. Hydrol. Process. 2008, 22, 2689-2698. [CrossRef]

40. Sun, G.; Zuo, C.; Liu, S.; Liu, M.; Mcnulty, S.G.; Vose, J.M. Watershed evapotranspiration increased due to changes in vegetation composition and structure under a subtropical climate1. J. Am. Water Resour. Assoc. 2008, 44, 1164-1175. [CrossRef]

41. Zhang, L.; Dawes, W.R.; Walker, G.R. Response of mean annual evapotranspiration to vegetation changes at catchment scale. Water Resour. Res. 2001, 37, 701-708. [CrossRef]

42. Koster, R.D.; Suarez, M.J. A simple framework for examining the interannual variability of land surface moisture fluxes. J. Clim. 1999, 12, 1911-1917. [CrossRef]

43. Milly, P.C.D.; Dunne, K.A. Macroscale water fluxes-2. Water and energy supply control of their interannual variability. Water Resour. Res. 2002, 38, 1-9. [CrossRef]

44. Li, L.J.; Zhang, L.; Wang, H.; Wang, J.; Yang, J.W.; Jiang, D.J.; Li, J.Y.; Qin, D.Y. Assessing the impact of climate variability and human activities on streamflow from the wuding river basin in China. Hydrol. Process. 2007, 21, 3485-3491. [CrossRef]

45. Helsel, D.R.; Hirsch, R.M. Statistical methods in water resources; US Geological Survey: Reston, VA, USA, 2002; Volume 323.

46. Liu, W.; Wei, X.; Liu, S.; Liu, Y.; Fan, H.; Zhang, M.; Yin, J.; Zhan, M. How do climate and forest changes affect long-term streamflow dynamics? A case study in the upper reach of Poyang river basin. Ecohydrology 2015, 8, 46-57. [CrossRef]

47. Tuteja, N.K.; Vaze, J.; Teng, J.; Mutendeudzi, M. Partitioning the effects of pine plantations and climate variability on runoff from a large catchment in southeastern Australia. Water Res. Res. 2007, 43, 199-212. [CrossRef]

48. Zhou, G.Y.; Wei, X.H.; Luo, Y.; Zhang, M.F.; Li, Y.L.; Qiao, Y.N.; Liu, H.G.; Wang, C.L. Forest recovery and river discharge at the regional scale of Guangdong province, China. Water Resour. Res. 2010, 46. [CrossRef]

49. Gafur, A.; Jensen, J.R.; Borggaard, O.K.; Petersen, L. Runoff and losses of soil and nutrients from small watersheds under shifting cultivation (Jhum) in the Chittagong hill tracts of Bangladesh. J. Hydrol. 2003, 274, 30-46. [CrossRef]

50. Scott, D.; Smith, R. Preliminary empirical models to predict reductions in total and low flows resulting from afforestation. Water SA. 1997, 23, 135-140.

51. Bruijnzeel, L.A. Hydrology of moist tropical forests and effects of conversion: A state of knowledge review. J. Hydrol. 1990, 129, 397-399.

52. Farley, K.A.; Jobbágy, E.G.; Jackson, R.B. Effects of afforestation on water yield: A global synthesis with implications for policy. Glob. Chang. Biol. 2005, 11, 1565-1576. [CrossRef]

53. Lan, C.; Lettenmaier, D.P.; Alberti, M.; Richey, J.E. Effects of a century of land cover and climate change on the hydrology of the puget sound basin. Hydrolog. Process. 2009, 23, 907-933.

54. Buttle, J.M.; Metcalfe, R.A. Boreal forest disturbance and streamflow response, northeastern Ontario. Can. J. Fish. Aquat. Sci. 2000, 57, 5-18. [CrossRef]

55. $\mathrm{Mu}, \mathrm{T}$. The estimation of transpiration of main tree species and water consumption of larch in Da Hinggan Moutains. Inn. Mong. For. Sci. Technol. 1980, 2, 3. 
56. Komatsu, H.; Tanaka, N.; Kume, T. Do coniferous forests evaporate more water than broad-leaved forests in Japan? J. Hydrol. 2007, 336, 361-375. [CrossRef]

57. Vertessy, R.; Zhang, L.; Dawes, W.R. Plantations, river flows and river salinity. Aust. For. 2003, 66, 55-61. [CrossRef]

58. Bosch, J.M.; Hewlett, J. A review of catchment experiments to determine the effect of vegetation changes on water yield and evapotranspiration. J. Hydrol. 1982, 55, 3-23. [CrossRef]

59. Moore, I.D.; Grayson, R.B.; Ladson, A.R. Digital terrain modelling: A review of hydrological, geomorphological, and biological applications. Hydrol. Process. 1991, 5, 3-30. [CrossRef]

60. Karlsen, R.H.; Grabs, T.; Bishop, K.; Buffam, I.; Laudon, H.; Seibert, J. Landscape controls on spatiotemporal discharge variability in a boreal catchment. Water Resour. Res. 2016, 52. [CrossRef]

61. Liu, W.; Wei, X.; Li, Q.; Fan, H.; Duan, H.; Wu, J.; Giles-Hansen, K.; Zhang, H. Hydrological recovery in two large forested watersheds of southeastern China: Importance of watershed property in determining hydrological responses to reforestation. Hydrol Earth Syst. Sci. 2016, 20, 4747-4756. [CrossRef]

62. Li, Q.; Wei, X.; Yang, X.; Giles-Hansen, K.; Zhang, M.; Liu, W. Topography significantly influencing low flows in snow-dominated watersheds. Hydrol. Earth Syst. Sci. 2018, 22, 1947. [CrossRef]

63. Price, K. Effects of watershed topography, soils, land use, and climate on baseflow hydrology in humid regions: A review. Prog. Phys. Geog. 2011, 35, 465-492. [CrossRef]

64. McGuire, K.J.; McDonnell, J.J.; Weiler, M.; Kendall, C.; McGlynn, B.L.; Welker, J.M.; Seibert, J. The role of topography on catchment-scale water residence time. Water Resour. Res. 2005, 41, 302-317. [CrossRef]

65. Brown, A.E.; Zhang, L.; McMahon, T.A.; Western, A.W.; Vertessy, R.A. A review of paired catchment studies for determining changes in water yield resulting from alterations in vegetation. J. hydrol. 2005, 310, $28-61$. [CrossRef]

66. Gauthier, S.; Vaillancourt, M.A. Ecosystem Management in the Boreal Forest; Presses de I'Université du Québec: Quebec, QC, Canada, 2009.

67. Liu, Q.; Yang, Z.; Cui, B.; Sun, T. Temporal trends of hydro-climatic variables and runoff response to climatic variability and vegetation changes in the yiluo river basin, China. Hydrol. Process. 2010, 23, 3030-3039. [CrossRef]

68. Zheng, H.X.; Zhang, L.; Zhu, R.R.; Liu, C.M.; Sato, Y.; Fukushima, Y. Responses of streamflow to climate and land surface change in the headwaters of the yellow river basin. Water Resour. Res. 2009, 45. [CrossRef]

69. Zhang, M.F.; Wei, X.H.; Sun, P.S.; Liu, S.R. The effect of forest harvesting and climatic variability on runoff in a large watershed: The case study in the upper Minjiang river of Yangtze river basin. J. Hydrol. 2012, 464, 1-11. [CrossRef]

70. Shi, P.; Ma, X.; Hou, Y.; Li, Q.; Zhang, Z.; Qu, S.; Chen, C.; Cai, T.; Fang, X. Effects of land-use and climate change on hydrological processes in the upstream of Huai river, China. Water Resour. Manag. 2013, 27, 1263-1278. [CrossRef]

71. Poff, N.L.; Allan, J.D.; Bain, M.B.; Karr, J.R.; Prestegaard, K.L.; Richter, B.D.; Sparks, R.E.; Stromberg, J.C. The natural flow regime. Bioscience 1997, 47, 769-784. [CrossRef]

72. Poff, N.L.; Zimmerman, J.K.H. Ecological responses to altered flow regimes: A literature review to inform the science and management of environmental flows. Freshwater Biol. 2010, 55, 194-205. [CrossRef]

73. Zanardo, S.; Harman, C.J.; Troch, P.A.; Rao, P.S.C.; Sivapalan, M. Intra-annual rainfall variability control on interannual variability of catchment water balance: A stochastic analysis. Water Resour. Res. 2012, 48. [CrossRef]

74. Bruijnzeel, L.A. Hydrological functions of tropical forests: Not seeing the soil for the trees? Agric. Ecosyst. Environ. 2004, 104, 185-228. [CrossRef]

75. Ellison, D.; Futter, M.N.; Bishop, K. On the forest cover-water yield debate: From demand- to supply-side thinking. Glob. Chang. Biol. 2012, 18, 806-820. [CrossRef]

76. Valipour, M. Importance of solar radiation, temperature, relative humidity, and wind speed for calculation of reference evapotranspiration. Arch. Agron. Soil Sci. 2015, 61, 239-255. [CrossRef]

77. Liu, X.; Zhang, D. Trend analysis of reference evapotranspiration in northwest china: The roles of changing wind speed and surface air temperature. Hydrol. Process. 2013, 27, 3941-3948. [CrossRef]

78. Valipour, M. Study of different climatic conditions to assess the role of solar radiation in reference crop evapotranspiration equations. Arch Agron. Soil Sci. 2015, 61, 679-694. [CrossRef] 
79. Kurylyk, B.L. Discussion of 'a simple thaw-freeze algorithm for a multi-layered soil using the Stefan equation' by Xie and Gough (2013). Permafrost Periglac. 2015, 26, 200-206. [CrossRef]

80. Kurylyk, B.L.; Hayashi, M.; Quinton, W.L.; McKenzie, J.M.; Voss, C.I. Influence of vertical and lateral heat transfer on permafrost thaw, peatland landscape transition, and groundwater flow. Water Resour. Res. 2016, 52, 1286-1305. [CrossRef]

81. Wang, T.; Yang, H.; Yang, D.; Qin, Y.; Wang, Y. Quantifying the streamflow response to frozen ground degradation in the source region of the yellow river within the budyko framework. J. Hydrol. 2018, 558, 301-313. [CrossRef]

82. Ding, Y.H.; Ren, G.Y.; Zhao, Z.C.; Xu, Y.; Luo, Y.; Li, Q.P.; Zhang, J. Detection, causes and projection of climate change over china: An overview of recent progress. Adv. Atmos. Sci. 2007, 24, 954-971. [CrossRef]

83. Liu, Y.; Zhuoxin, G.U.; Wang, X. Impact of simulated climate warming on the radial growth of larix gmelinii in northeast china. Acta Ecologica Sinica 2017, 37, 2684-2693.

84. Jin, H.J.; Yu, Q.H.; Lii, L.Z.; Guo, D.X.; He, R.X.; Yu, S.P.; Sun, G.Y.; Li, Y.W. Degradation of permafrost in the Xing'anling mountains, northeastern china. Permafrost Periglac. 2007, 18, 245-258. [CrossRef]

85. Chang, X.; Jin, H.; He, R.; Yang, S.; Yu, S.; Lv, L.; Guo, D.; Wang, S.; Kang, X. Advances in permafrost and cold regions environments studies in the da Xing'anling (Da Hinggan) mountains, northeastern China. J. Glaciol Geocryol 2008, 30, 176-182.

(C) 2018 by the authors. Licensee MDPI, Basel, Switzerland. This article is an open access article distributed under the terms and conditions of the Creative Commons Attribution (CC BY) license (http:/ / creativecommons.org/licenses/by/4.0/). 